\title{
Human Embryo Research: Yes or No?
}

\section{THE CIBA FOUNDATION}

Experimental research on early human embryos is an emotive subject. Most of the public debate has so far centred on moral issues rather than on scientific aspects such as the needs and possibilities of research.

In 1985 the Ciba Foundation held a unique meeting to provide a forum in which scientists, moral philosophers, doctors, and lawyers could discuss the issues raised by embryo research. This book records the fascinating and informative exchanges that took place.

\section{6 pages}

Hardback $0422504905 £ 17.95$

Paperback $0422606006 £ 6.95$

\section{TAVISTOCK}

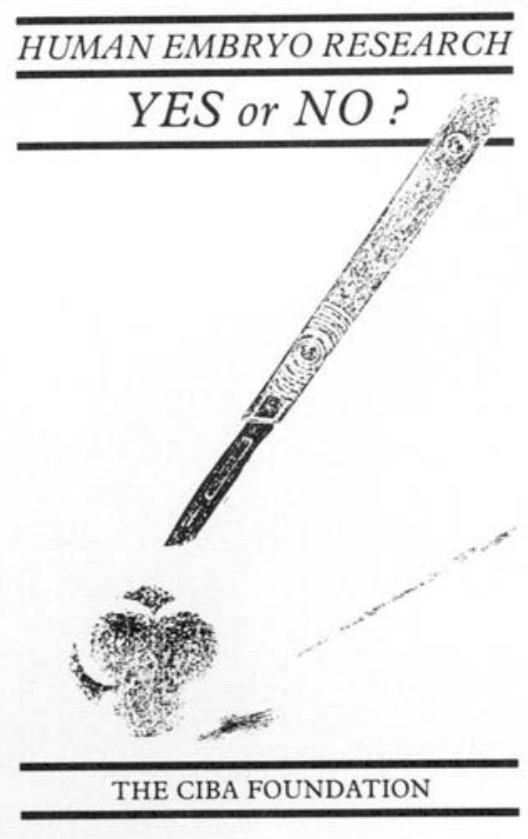




\section{Genetical Research}

EDITORIAL BOARD

CHARLOTTE AUERBACH ARTHUR CHOVNICK W. HAYES

BRUCE HOLLOWAY D. ISH-HOROWICZ MARY F. LYON

ANNE MCLAREN M. VAN MONTAGU R. NÖTHIGER J. PAUL

W. J. PEACOCK PETER A. PETERSON R. H. PRITCHARD

R. RILEY A. ROBERTSON N.S. WILLETTS

EXECUTIVE EDITOR

E. C. R. REEVE

ASSISTANT EXECUTIVE EDITORS

DAVID J. FINNEGAN TRUDY F. C. MACKAY

\section{Volume 481986}

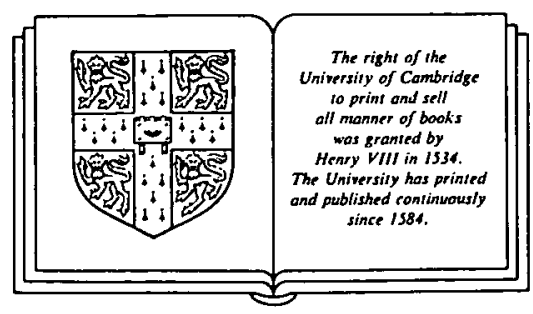

CAMBRIDGE UNIVERSITY PRESS

CAMBRIDGE

LONDON NEW YORK NEW ROCHELLE

MELBOURNE SYDNEY 
Published by

The Press Syndicate of the University of Cambridge

The Pitt Building, Trumpington Street, Cambridge CB2 IRP

32 East 57th Street, New York, NY 10022

10 Stamford Road, Oakleigh, Melbourne 3166, Australia

(C) Cambridge University Press, 1986

Printed in Great Britain by the University Press, Cambridge 


\section{Contents}

\section{No. 1 (August 1986)}

DEAN, ANTHONY M., DYKHUIZEN, DANIEL E. and HARTL, DANIEL L. Fitness as a function of $\beta$-galactosidase activity in Escherichia coli

hoekstra, MERL F., NAUghton, tom and MALOne, ROBERT e. Properties of spontaneous mitotic recombination occurring in the presence of the rad52-1 mutation of Saccharomyces cerevisiae

GOLENBERG, EDWARD M. Chromosomal location of peptidase, PEPT-1, genes in Triticum aestivum var. Chinese Spring

GOUX, JEAN-MICHEL and PASTEUR, GEORGES. A sex-linked enzyme in a reptile-association with a recent centric fusion in the common lizard

HARTL, G. B. and HOGER, H. Biochemical variation in purebred and crossbred strains of domestic rabbits (Oryctolagus cuniculus L.)

LAMOREUX, M. LYNN and GALBRAITH, DONALD B. DK/Lm: A Strain of Laboratory Mouse with an Unusual Expression of the Lethal Yellow $\left(A^{y}\right)$ Phenotype

HILL, WILliam G. and RASBASH, JONATHAN. Models of long term artificial selection in finite population

ERR A TUM

BOOK REVIEWS

\section{No. 2 (October 1986)}

GUZMAN, ELENA C. and JIMENEZ-SANCHEZ, ALFONSO. Effect of multiple copies of rpoBC on the rate of RNA synthesis in Escherichia coli

MUKHERJEE, A. S. and GHOSH, MITA. A different level of $X$-chromosomal transcription in an $\ln (1) \mathrm{BM}^{2}$ (reinverted) strain and in its hyperploid derivatives resolves an $X$-coded regulatory activity for dosage compensation in Drosophila

MACKAY, TRUDY F. C. Transposable element-induced fitness mutations in Drosophila melanogaster

FITZPATRICK, BENJAMIN J. and SVED, JOHNA. High levels of fitness modifers induced by hybrid dysgenesis in Drosophila melanogaster

LYNCH, CAROL BECKER, ROBERTS, R. C. and HILL, W. G. Heterosis among lines of mice selected for body weight. 3. Thermoregulation

HETZEL, D. J. S. and NICHOLAS, F. W. Growth, efficiency and body composition of mice selected for post-weaning weight gain on ad libitum or restricted feeding

CHARLESWORTH, BRIAN. Genetic divergence between transposable elements

HILL, WILLIAM G. and RASBASH, JONATHAN. Models of long-term artificial selection in finite population with recurrent mutation 
No. 3 (December 1986)

YAMAMOTO, NOBUTO and MCDONALD, ROBERT J. Genomic structure of phage F22, a hybrid between serologically and morphologically unrelated Salmonella typhimurium bacteriophages $\mathrm{P} 22$ and $\mathrm{Fels} 2$

PIZZIRANI-KLEINER, ALINE A. and AZEVEDO, J. L. Effect of the $b n c A$ gene on the instability of Aspergillus nidulans

IRD, STEPHEN R. and SEMEONOFF, ROBERT. Selection for oviposition preference in Drosophila melanogaster

ONTCHAM P-MOREAU, CATHERINE and KATZ, MARIANO. A theoretical analysis of linkage disequilibrium produced by genetic drift in Drosophila populations

TERRACOL, RÉGINE. Transcription of rDNA insertions in bobbed mutants of Drosophila melanogaster

NADEAU, JOSEPH H. A chromosomal segment conserved since divergence of lineages leading to man and mouse: The gene order of aminoacylase-1, transferrin, and beta-galactosidase on mouse Chromosome 9

PENNYCUIK, PAMELA R., RAPHAEL, KATHRYNA., CHAPMAN R. E. and HARDY, MARGARET H. The site of action of the asebia locus $(a b)$ in the skin of the mouse

TAKAHATA, NAOYUKI. An attempt to estimate the effective size of the ancestral species common to two extant species from which homologous genes are sequenced

VANLERBERGHE, F., DOD, B., BOURSOT, P., BELLIS, M. and BONHOMME, F. Absence of Y-chromosome introgression across the hybrid zone between Mus musculus domesticus and Mus musculus musculus

SANYAL, S., VAN NIE, R., DE MOES, J. and HAWKINS, R. K. Map position of dysgenetic lens $(d y l)$ locus on chromosome 4 in the mouse 


\section{NOTES TO CONTRIBUTORS}

GENETICAL RESEARCH publishes original work on all aspects of genetics, or in any field of research which has an important bearing on genetics. Reviews of topical interest will also be considered. Papers will be submitted to referees, and will generally be printed in order of acceptance. Short papers (see below) will be given priority in publication.

CONTRIBUTIONS are welcomed from scientists of all nationalities, but must be written in English. Papers should be sent to the Executive Editor, Dr E. C. R. Reeve, Institute of Animal Genetics, West Mains Road, Edinburgh EH9 $3 \mathrm{JN}$, or to a member of the Editorial Board with a particular interest in that area of genetics. Submission of a paper will be taken to imply that it is unpublished and is not being considered for publication elsewhere. Papers should be as concise as clarity permits, and illustrations should be restricted to the minimum needed.

SHORT PAPERS This category is designed for concisely written reports of work for which rapid publication is considered desirable. Such papers will normally be published within three months of receipt in acceptable form. They should not exceed 4 pages of print in length, and should include a summary.

TYPESCRIPTS A top copy and two other copies should be submitted. The top copy should be typed with double-spacing on one side of good quality paper, leaving margins of about $1 \frac{1}{2}$ inches at the left-hand side and at the top and bottom of each sheet. Each copy should include a complete set of illustrations. The title should ordinarily identify the organism. The address of the laboratory at which the work was carried out will be printed with the authors' names at the head of the paper, and changes of address may be added in footnotes. A footnote to the title page should also give the name and address to whom reprint requests may be made. Sources of financial support should be included with other acknowledgements at the end of the text. The title page of the typescript should include a short title for running headlines (limited to 50 letters and spaces), and the name and address of the author (or his proxy) to whom the proofs are to be sent, under the heading: Proofs to be sent to... Main headings should be typed in capitals and (except summary and references) numbered consecutively. Subheadings should be typed in lower case, and underlined except for those words and symbols which would be italicized in the text. Subheadings should be numbered (i), (ii), etc., within each main heading. Numeral 1 and letter el: if your typewriter uses one symbol for both, please make clear to the Printer which is intended in formulae, gene symbols, etc.

SUMMARY The summary will be printed at the beginning of the paper. It should give a concise abstract of the significant content and conclusions of the paper, in a form suitable for abstracting journals to use, and should not exceed 250 words.

ILLUSTRATIONS The separate category of Plates no longer applies in the new format. All illustrations, including photographs, diagrams, graphs etc. are to be labelled consecutively Figure $1,2 \ldots$ according to their relative positions in the text. Each figure should have a legend to be printed underneath it. Photographs should be supplied as unmounted glossy prints, with a sketch or separate set to show the arrangement required when several photographs are to form one figure. The names of the authors and the orientation of the figure should be indicated on the back of each photograph. Diagrams should be about twice the size of the printed figure, but not larger than $12 \times 8$ inches, unless exceptionally complicated, and the thickness of lines and size of points should be determined accordingly. They may be submitted as glossy photographic prints or be drawn in indian ink on white Bristol-board, tracing linen or graph paper ruled in pale blue (but not other colours). The lettering on drawings should be lightly inserted in soft pencil only, so that the printer can put in the finished lettering. Legends to illustrations must be given on a separate sheet of paper. Each illustration must have the name of the author and figure number pencilled on the back.

TABLES Each table should be typed on a separate sheet of paper and its approximate position in the text indicated on the typescript. Each should be numbered and carry an appropriate title. The table should be designed, whenever possible, to be printed in the normal orientation of the text. The data should be grouped so as to make the use of rules unnecessary. Vertical rules, in particular, are expensive to print, and will only be included at the Editor's discretion. Table footnotes should ordinarily employ the symbols ${ }^{*}, \dagger$ $\ddagger, \S, \|, \uparrow,{ }^{* *}$, etc., in that order.

SYмBOLS Gene and mathematical symbols should generally be printed in italics. Please underline those to be italicized when they appear in the text and tables. Bold letters add to printing costs and should only be used where they are necessary to avoid confusion. The author must assume responsibility for the accurate printing of complex mathematical formulae submitted in typewritten form, by differentiating between letters and numbers which are open to misinterpretation, and identifying all Greek, Hebrew and script letters by means of marginal notes at their first appearance. Note that Greek symbols cannot be italicized and that ' + ' as the symbol for a wild-type allele should not be italicized.

NOMENCLATURE Wherever possible, standardized nomenclature should be employed. The author should refer to the following publications for guidance: Novick et al (Bacteriological Reviews 40, 168-189) for plasmids; O'Brien (Ed.), Genetic Maps 3, Cold Spring Harbor 1984, for recent information on most species and recent gene lists.

REFERENCES should follow the normal usage in the journal In the list of references at the end of the paper, both titles of articles and names of periodicals should be written out in full.

PROOFS Two sets of single-sided page proofs, together with the typescript of each paper will be sent to the author. The printers' marked proof should be returned after correction to the Executive Editor, together with the typescript. Excessive alterations, other than corrections of printers' errors, may be disallowed or charged to the author. Correction should be made using the symbols in British Standard 1219: 1958, or its shortened version B.S. 1219C: 1958.

OFFPRINTS Fifty offprints of each paper, or short paper, are provided free of charge. Additional offprints may be ordered in the form sent out with proofs, provided this is returned within fourteen days of receipt. 


\section{Volume 48 No 3 December 1986}

\section{Genetical Res., Camb.

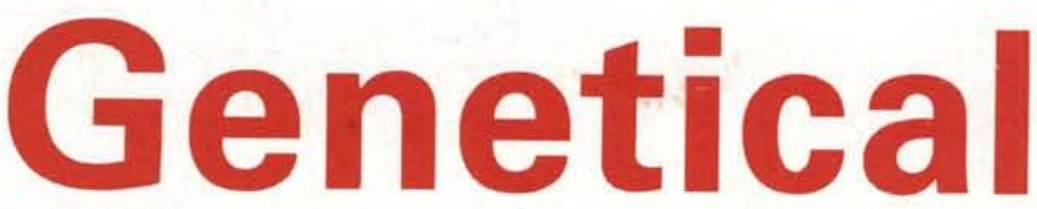 \\ Research}

\section{Contents}

YAMAMOTO, NOBUTO and MCDONALD, ROBERT J. Genomic structure of phage F22, a hybrid between serologically and morphologically unrelated Salmonella typhimurium bacteriophages P22 and Fels 2

145 PIZZIRANI-KLEINER, ALINEA. and AZEVEDO, J. L. Effect of the $b n c A$ gene on the instability of Aspergillus nidulans

151 BIRD, STEPHEN R. and SEMEONOFF, ROBERT. Selection for oviposition preference in Drosophila melanogaster

161 MONTCHAMP-MOREAU, CATHERINE and KATZ, MARIANO. A theoretical analysis of linkage disequilibrium produced by genetic drift in Drosophila populations

167 TERRACOL, REGINE. Transcription of rDNA insertions in bobbed mutants of Drosophila melanogaster

175 NADEAU, JOSEPH H. A chromosomal segment conserved since divergence of lineages leading to man and mouse: The gene order of aminoacylase-1, transferrin, and beta-galactosidase on mouse Chromosome 9

179 PENNYCUIK, PAMELAR., RAPHAEL, KATHRYN A., CHAPMAN, R. E. and HARDY, MARGARETH. The site of action of the asebia locus $(a b)$ in the skin of the mouse

187 TAKAHATA, NAOYUKI. An attempt to estimate the effective size of the ancestral species common to two extant species from which homologous genes are sequenced

191 VANLERBERGHE, F., DOD, B., BOURSOT, P., BELLIS, M. and BONHOMME, F. Absence of $\mathrm{Y}$-chromosome introgression across the hybrid zone between Mus musculus domesticus and Mus musculus musculus

199 SANYAL, S., VAN NIE, R., DE MOES, J. and HAWKINS, R. K. Map position of dysgenetic lens $(d y /)$ locus on chromosome 4 in the mouse

201 BOOKREVIEWS

209 BOOKS RECEIVED

211 INDEX

(C) Cambridge University Press 1986

\section{Cambridge University Press}

The Pitt Building, Trumpington Street, Cambridge CB2 1RP

32 East 57th Street, New York, NY 10022, USA

10 Stamford Road, Oakleigh, Melbourne 3166, Australia

Printed in Great Britain by the University Press, Cambridge 